\title{
RECOGNITION OF MAIN PROCESSES FORMING CHEMICAL COMPOSITION OF THE SUPRAŚL RIVER WATER
}

\section{Mirosław Skorbiłowicz}

1 Department of Technology in Engineering and Environmental Protection, Bialystok University of Technology, Wiejska Str. 45A, 15-351 Białystok, Poland, e-mail: m.skorbilowicz@pb.edu.pl

Received: 2015.10 .26

Accepted: 2015.12.09

Published: 2016.01.06

\begin{abstract}
The aim of the study was to identify and define the processes that affect the variability of the chemical composition of Supraśl river water at selected measuring points. One of the recognized multivariate statistical methods was used for identification. The research area covered the Suprasl river. Four measuring points were selected on the river - Michałowo, Gródek, Nowodworce, Dzikie. The measuring points were selected in such a way to take into account the impact of the most intense interaction located along the river. Changes in concentration were determined on the basis of monthly analyzes of water samples collected from the Supraśl river in 2003-2012 by the Regional Inspectorate for Environmental Protection (RIEP) in Białystok. The analyses were performed in the RIEP laboratory in Bialystok, which has implemented and maintained a management system that meets the requirements of the norm PN-EN ISO/IEC 17025 + Ap.1:2007 approved by the certificate AB 165. The water samples were subject to determinations of dissolved oxygen concentration, $\mathrm{BOD}_{5}, \mathrm{COD}_{\mathrm{Mn}}, \mathrm{COD}_{\mathrm{Cr}}, \mathrm{NH}_{3}$, $\mathrm{N}-\mathrm{NH}_{4}^{+}, \mathrm{N}_{\text {Kieldahl }}, \mathrm{NO}_{3}^{-}, \mathrm{N}-\mathrm{NO}_{3}{ }^{-}, \mathrm{NO}_{2}^{-}, \mathrm{N}-\mathrm{NO}_{2}{ }^{-}, \mathrm{N}_{\text {tot. }}, \mathrm{PO}_{4}{ }^{3-}, \mathrm{P}_{\text {tot }}$ and electrical conductivity value. The monthly sum of precipitation was read based on data from the Weather Service "IMGW-PIB Monitor". The research and analysis results allowed to identify the self-cleaning, nitrification, and de-nitrification processes, as well as enrichment affecting the variability of the chemical composition of the Supraśl river water. The results from the factor analysis showed some prevailing of enrichment processes over internal changes in the aquatic environment of the Supraśl river.
\end{abstract}

Keywords: chemical composition, river water, multivariate statistical method.

\section{INTRODUCTION}

The study upon factors affecting the variability of chemical composition of water outflow from the upper Narew river catchment, including Supraśl river, and determination of their sources were conducted by Banaszuk and Wysocka [1996], Mioduszewski [1997], Banaszuk H. [2004] and Banaszuk P. [2007]. Other research carried out by Grabowska et al. [2003], Górniak [2006], as well as Zieliński and JekaterynczukRudczyk [2009] the most often related to the catchment fragment associated with selected river or reservoir. According to Skorbiłowicz and Kiryluk [2005], the quality of the Supraśl river water periodically changes, mainly in relation to the content of $\mathrm{N}_{-} \mathrm{NH}_{4}^{+}, \mathrm{NO}_{2}^{-}$and $\mathrm{NO}_{3}^{-}$. The authors argue that indirectly, the quality of the Supraśl river water is influenced by methods of adjacent land use, mainly including the post-bog meadows, as well as the migration of pollutants from other, non-agricultural sources. Prevailing part of the Supraśl river catchment is abundant in moorshed muck soils characterized by a high content of nitrogen forms released by mineralization of soil. Skorbiłowicz [2006] conducted a factor analysis of the results of the items concentrations in water samples from the whole Supraśl river. The analyses allowed to identify two factors, the first of which explained $57 \%$ of the chemical composition variation of the Supraśl river and the other $30 \%$. The factor analysis also performed 
by Skorbiłowicz [2010], involving results of the Supraśl river water, enabled the identification of two factors. Factor I explained the variability of chemical composition of the Supraśl river waters in $76 \%$, while factor II in $14 \%$. The author identified sources of minerals in the catchment area of the river Supraśl, which included among others, wastewater produced mainly in Michałowo and Gródek. Skorbiłowicz and Ofman [2015] showed that the unit loads of $\mathrm{Ca}^{2+}$ and $\mathrm{Mg}^{2+}$ in the Supraśl river water were positively correlated $(\mathrm{r}=0.79$ and $r=0.85$ ) with the amount of liming in soils of the Supraśl river catchment that is closed by Dzikie intersection.

The aim of the study was to identify and define the processes affecting the variability of the chemical composition in Supraśl river water at selected measuring points. One of the recognized multivariate statistical methods was used for identification.

\section{METHODS}

The Supraśl river with a length of $93.8 \mathrm{~km}$ and catchment area of $1844.4 \mathrm{~km}^{2}$ is the right tributary of the Narew river with an estuary of $299.8 \mathrm{~km}$. The springs of the river are located north of the village Topolany, in the area of extensive peat bogs. The catchment area up to the village Gródek is of a lowland nature with marshpeat subsoil. The catchment area of the river is covered with The Knyszyńska Forest Landscape Park. Its borders surround a prevailing fragment of Knyszyńska Forest - one of the best preserved forest complexes in Poland. Forests cover 80\% of the Park area. They have a remarkably Boreal character, similar to that of the southern taiga. Pines and pine-spruce trees, sometimes older than a century, dominate. The Knyszyńska Forest with area of 132,372 hectares is Natura 2000 protected area. The Suprasl river is a source of drinking water supply for Bialystok agglomeration, therefore its catchment is covered by the indirect protection zone. Annual precipitation ranges from 500 to $600 \mathrm{~mm}$. The studied valley contains mainly hydrogenic soils - moorshed ones occupying approximately $70 \%$ of the area. Organic soils predominate on the broad, flat valley sections of Upper and Lower Supraśl river, where they cover about $70 \%$ of the area. They occupy $56 \%$ of the area within a relatively narrow Middle Supraśl river valley. On this stretch of the river, the catchment areas are dominated by forests (approximately $63 \%$ of the total area).

The study area included the Supraśl river. Four measuring points were selected on the river - Michałowo, Gródek, Nowodworce, Dzikie (Figure 1).

The measuring points were selected in such a way to take into account the impact of the most intense interactions located along the river. Changes in the concentration were determined on the basis of monthly analyzes of water samples collected from the Supraśl river in 2003-2012 by the Regional Inspectorate for Environmental Protection (RIEP) in Białystok. Analyses were performed by RIEP laboratory in Bialystok, that has implemented and maintained a management system, which meets the requirements of the norm PN-EN ISO/IEC 17025 + Ap.1:2007 confirmed by the certificate $A B$ 165. The water samples were subject to determinations of dissolved oxygen concentration, $\mathrm{BOD}_{5}, \mathrm{COD}_{\mathrm{Mn}}, \mathrm{COD}_{\mathrm{Cr}}, \mathrm{NH}_{3}$, $\mathrm{N}-\mathrm{NH}_{4}^{+}, \mathrm{N}_{\text {Kieldahl, }}, \mathrm{NO}_{3}^{-}, \mathrm{N}-\mathrm{NO}_{3}^{-}, \mathrm{NO}_{2}^{-}, \mathrm{N}-\mathrm{NO}_{2}^{-}$, $\mathrm{N}_{\text {tot. }}, \mathrm{PO}_{4}^{3-}, \mathrm{P}_{\text {tot }}$ and electrical conductivity.

The monthly sum of precipitation was read based on a data from the Weather Service "IMGW-PIB Monitor" [http://monitor.pogodynka.pl/\#map/19.533,52.1384,7,false,true,0].

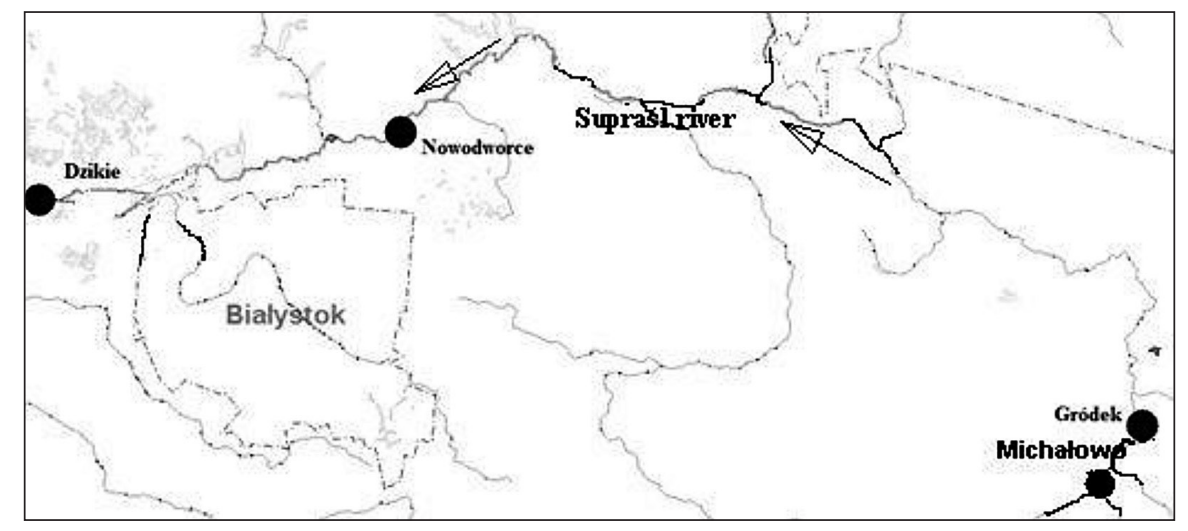

Figure 1. Localization of the measuring points on the Supraśl river 
Statistical processing of the test results used the factor analysis that belongs to the group of multidimensional analysis and is used to describe and explore a large number of data. The hydrochemical studies use it to describe the processes occurring in surface waters and groundwater and identification of the supply sources as well as the origin of substances affecting the chemical composition of water. In order to interpret the results of factor analysis, it was assumed that the association of the primary variable with the factor is strong when the absolute values of its loads are greater than 0.70 . Values of so-called general statistics were also calculated, in particular: arithmetic mean, standard deviation, and variation coefficient. The licensed software package StatSoft Statistica 12 was applied for all calculations.

\section{RESULTS AND DISCUSSION}

The largest spread of the test results of Supraśl river water samples occurred at point Michałowo in the case of $\mathrm{BOD}_{5}$ (variability coefficient $330.41 \%$ ), while the smallest - for electrical conductivity of water (variability coefficient $10.21 \%$ ). Quite significant result dispersion was recorded for $\mathrm{NH}_{3}$ and $\mathrm{N}-\mathrm{NH}_{4}^{+}(156.90 \%)$ and for $\mathrm{PO}_{4}^{3-}$ and $\mathrm{P}_{\text {tot }}(105.72 \%$ and $102.60 \%$, respectively) (Table 1 ). The remaining variability coefficients reached lower, yet very similar values. A great scatter of results around their mean value may indicate some factor or process that invokes them. The water quality indicator expressed as $\mathrm{BOD}_{5}$ is a measure of readily-decomposable organic matter content. The results of factor analysis (Table 2) also indicate the presence of factor I correlated with factorial loads of variables $\mathrm{BOD}_{5}$, $\mathrm{NH}_{3}, \mathrm{~N}_{-} \mathrm{NH}_{4}^{+}, \mathrm{N}_{\text {Kieldahl }}$, as well as $\mathrm{PO}_{4}^{3-}, \mathrm{P}_{\text {tot }}$. This factor is associated with penetration of readily-decomposable organic matter $\left(\mathrm{BOD}_{5}\right)$, nitrogen and phosphorus compounds being the components of poorly purified municipal wastewater into the water of Supraśl river before point Michałowo. The other factor is negatively correlated with dissolved oxygen and with $\mathrm{NO}_{3}^{-}$and $\mathrm{N}_{-} \mathrm{NO}_{3}^{-}$, while positively with $\mathrm{NO}_{2}^{-}$and $\mathrm{N}_{-} \mathrm{NO}_{2}^{-}$, which may suggest de-nitrification processes occurring in water of that fragment of Supraśl river. The former factor explains up to $50 \%$ of processes that site, whereas the latter only $18 \%$, indicating a great surplus of Supraśl river water enrichment against the conversion of components that entered the aquatic environment.

At the measuring point Gródek, the largest scatter of results related to the Supraśl river water was recorded for $\mathrm{PO}_{4}{ }^{3-}$ and $\mathrm{P}_{\text {tot }}(88.57 \%$ and $76.15 \%)$ as well as $\mathrm{N}^{-\mathrm{NH}_{4}^{+}}(70.82 \%)$ (Table 3), which may result from the discharge of insufficiently purified wastewater in that region. These may be wastewater discharged to the Supraśl river by municipal sewage treatment plants in Michałów and Gródek. A slight dispersion of results $(10.41 \%)$ for electrical conductivity of the

Table 1. Mean concentration of components in the Supraśl river water at the measuring point Michałowo

\begin{tabular}{|c|c|c|c|c|c|c|c|}
\hline Parameter & Unit & $\begin{array}{l}\text { Number of } \\
\text { samples }\end{array}$ & Arithmetic mean & Minimum & Maximum & $\begin{array}{l}\text { Standard } \\
\text { deviation }\end{array}$ & $\begin{array}{c}\text { Variability } \\
\text { coefficient [\%] }\end{array}$ \\
\hline Precipitation & {$[\mathrm{mm}]$} & 84 & 54.62 & 0.08 & 225.20 & 35.13 & 64.31 \\
\hline Dissolved oxygen & {$\left[\mathrm{mgO}_{2} \cdot \mathrm{dm}^{-3}\right]$} & 46 & 5.71 & 0.60 & 10.20 & 2.71 & 47.42 \\
\hline $\mathrm{BOD}_{5}$ & {$\left[\mathrm{mgO}_{2} \cdot \mathrm{dm}^{-3}\right]$} & 46 & 5.82 & 0.90 & 133.00 & 19.22 & 330.41 \\
\hline $\mathrm{COD}_{\mathrm{Mn}}$ & {$\left[\mathrm{mgO}_{2} \cdot \mathrm{dm}^{-3}\right]$} & 46 & 18.54 & 9.00 & 78.00 & 10.09 & 54.41 \\
\hline $\mathrm{COD}_{\mathrm{Cr}}$ & {$\left[\mathrm{mgO}_{2} \cdot \mathrm{dm}^{-3}\right]$} & 46 & 72.08 & 24.00 & 279.40 & 35.45 & 49.18 \\
\hline $\mathrm{NH}_{3}$ & {$\left[\mathrm{mg} \cdot \mathrm{dm}^{-3}\right]$} & 44 & 1.91 & 0.15 & 16.10 & 3.00 & 156.90 \\
\hline $\mathrm{N}-\mathrm{NH}_{4}^{+}$ & {$\left[\mathrm{mg} \cdot \mathrm{dm}^{-3}\right]$} & 44 & 1.48 & 0.12 & 12.50 & 2.33 & 156.90 \\
\hline $\mathrm{N}_{\text {Kieldahl }}$ & {$\left[\mathrm{mg} \cdot \mathrm{dm}^{-3}\right]$} & 46 & 2.85 & 1.20 & 12.80 & 2.51 & 87.90 \\
\hline $\mathrm{NO}_{3}^{-}$ & {$\left[\mathrm{mg} \cdot \mathrm{dm}^{-3}\right]$} & 45 & 16.17 & 0.66 & 49.10 & 9.60 & 59.36 \\
\hline $\mathrm{N}-\mathrm{NO}_{3}^{-}$ & {$\left[\mathrm{mg} \cdot \mathrm{dm}^{-3}\right]$} & 33 & 3.35 & 0.15 & 8.41 & 1.91 & 57.04 \\
\hline $\mathrm{NO}_{2}^{-}$ & {$\left[\mathrm{mg} \cdot \mathrm{dm}^{-3}\right]$} & 46 & 0.21 & 0.05 & 0.53 & 0.13 & 64.89 \\
\hline $\mathrm{N}-\mathrm{NO}_{2}^{-}$ & {$\left[\mathrm{mg} \cdot \mathrm{dm}^{-3}\right]$} & 34 & 0.06 & 0.02 & 0.16 & 0.04 & 66.19 \\
\hline $\mathrm{N}_{\text {tot }}$ & {$\left[\mathrm{mg} \cdot \mathrm{dm}^{-3}\right]$} & 46 & 6.50 & 2.80 & 13.10 & 2.39 & 36.77 \\
\hline $\mathrm{PO}_{4}^{3-}$ & {$\left[\mathrm{mg} \cdot \mathrm{dm}^{-3}\right]$} & 46 & 0.98 & 0.15 & 4.96 & 1.03 & 105.72 \\
\hline$P_{\text {tot }}$ & {$\left[\mathrm{mg} \cdot \mathrm{dm}^{-3}\right]$} & 46 & 0.41 & 0.06 & 1.76 & 0.42 & 102.60 \\
\hline Electrical conductivity & {$\left[\mu \mathrm{S} \cdot \mathrm{cm}^{-1}\right]$} & 46 & 469.04 & 383.00 & 648.00 & 47.90 & 10.21 \\
\hline
\end{tabular}


Table 2. Results of the factor analysis (rotation method - normalized varimax, determined loads are $>0.7$ ). Measuring point Michałowo

\begin{tabular}{|l|c|c|}
\hline \multicolumn{1}{|c|}{ Variables } & Factor I & Factor II \\
\hline Precipitation & -0.15 & 0.66 \\
\hline Dissolved oxygen & -0.49 & -0.75 \\
\hline $\mathrm{BOD}_{5}$ & $\mathbf{0 . 7 5}$ & 0.12 \\
\hline $\mathrm{COD}_{\mathrm{Mn}}$ & -0.57 & -0.19 \\
\hline $\mathrm{COD}_{\mathrm{Cr}}$ & -0.59 & -0.07 \\
\hline $\mathrm{NH}_{3}$ & $\mathbf{0 . 9 5}$ & 0.16 \\
\hline${\mathrm{N}-\mathrm{NH}_{4}{ }^{+}}^{\mathrm{N}_{\text {Kieldahl }}}$ & $\mathbf{0 . 9 5}$ & 0.16 \\
\hline $\mathrm{NO}_{3}^{-}$ & $\mathbf{0 . 9 4}$ & 0.16 \\
\hline${\mathrm{N}-\mathrm{NO}_{3}^{-}}^{-}$ & -0.45 & -0.78 \\
\hline $\mathrm{NO}_{2}^{-}$ & -0.45 & -0.78 \\
\hline${\mathrm{N}-\mathrm{NO}_{2}^{-}}^{-}$ & 0.10 & $\mathbf{0 . 7 9}$ \\
\hline $\mathrm{N}_{\text {tot }}$ & 0.10 & $\mathbf{0 . 7 9}$ \\
\hline $\mathrm{PO}_{4}{ }^{-}$ & 0.65 & -0.51 \\
\hline $\mathrm{P}_{\text {tot }}$ & $\mathbf{0 . 8 5}$ & 0.35 \\
\hline Electrical conductivity & $\mathbf{0 . 8 7}$ & 0.35 \\
\hline $\begin{array}{l}\text { Explanation of chemical } \\
\text { composition in the Supraśl river } \\
\text { water by factor I and II [\%] }\end{array}$ & 0.69 & -0.03 \\
\hline
\end{tabular}

Supraśl river water was observed. Based on the factor analysis (Table 4), two factors were identified, of which the first explains $37 \%$ of the chemical composition of the Supraśl river water, while the other $20 \%$. The former factor indicates the self-cleaning processes occurring in water of the studied river. Significant factorial load represent- ing the water-dissolved oxygen indicates a factor making its supply to the Supraśl river water. At the same time, the analysis suggests nitrification processes due to probable internal correlation at the level of the factor between dissolved oxygen vs. $\mathrm{NO}_{3}^{-}, \mathrm{N}_{-} \mathrm{NO}_{3}^{-}$. The analysis has shown negative factorial loads representing phosphorus compounds $\left(\mathrm{PO}_{4}^{3-}, \mathrm{P}_{\text {tot }}\right)$, which may be a consequence of the self-cleaning processes in the studied water. This can be explained by the oxygen produced due to photosynthesis and the use of phosphorus compounds by developing mono and multicellular plant organisms. The latter factor indicates the processes of enriching in $\mathrm{N}^{-\mathrm{NH}_{4}}{ }^{+}$resulting from the discharge of insufficiently treated wastewater.

Water of the Supraśl river (point Nowodworce) contained the most variable concentration of $\mathrm{NO}_{2}^{-}(267.03 \%)$, which may indicate the intense nitrification processes occurring in water before this point. A slight scatter of dissolved oxygen results $(23.35 \%)$ seems to confirm this phenomenon. A subsequent case of very slight variability of electrical conductivity $(7.07 \%)$ for studied water, was recorded (Table 5).

Factor analysis (Table 6) indicates the supply of organic matter expressed as $\mathrm{COD}_{\mathrm{Mn}}, \mathrm{COD}_{\mathrm{Cr}}$, including the hardly decomposable one, as well

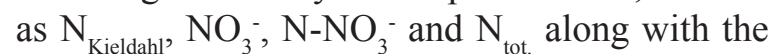
decrease in water electrical conductivity. The enrichment in these components can happen due to the penetration of runoff from surrounding fields into the Supraśl river. At the point Nowod-

Table 3. Mean concentration of components in the Supraśl river water at the measuring point Gródek

\begin{tabular}{|l|c|c|c|c|c|c|c|}
\hline \multicolumn{1}{|c|}{ Parameter } & Unit & $\begin{array}{c}\text { Number of } \\
\text { samples }\end{array}$ & Arithmetic mean & Minimum & Maximum & $\begin{array}{c}\text { Standard } \\
\text { deviation }\end{array}$ & $\begin{array}{c}\text { Variability } \\
\text { coefficient [\%] }\end{array}$ \\
\hline Precipitation & {$[\mathrm{mm}]$} & 84 & 54.62 & 0.08 & 225.20 & 35.13 & 64.31 \\
\hline Dissolved oxygen & {$\left[\mathrm{mgO}_{2} \cdot \mathrm{dm}^{-3}\right]$} & 75 & 6.95 & 0.60 & 13.70 & 2.49 & 35.79 \\
\hline $\mathrm{BOD}_{5}$ & {$\left[\mathrm{mgO}_{2} \cdot \mathrm{dm}^{-3}\right]$} & 75 & 3.24 & 1.20 & 14.30 & 2.05 & 63.37 \\
\hline $\mathrm{COD}_{\mathrm{Mn}}$ & {$\left[\mathrm{mgO}_{2} \cdot \mathrm{dm}^{-3}\right]$} & 58 & 22.78 & 7.00 & 73.10 & 11.31 & 49.63 \\
\hline $\mathrm{COD}_{\mathrm{Cr}}$ & {$\left[\mathrm{mgO}_{2} \cdot \mathrm{dm}^{-3}\right]$} & 58 & 85.66 & 20.50 & 243.00 & 36.82 & 42.98 \\
\hline $\mathrm{NH}_{3}$ & {$\left[\mathrm{mg} \cdot \mathrm{dm}^{-3}\right]$} & 63 & 0.55 & 0.08 & 2.00 & 0.37 & 67.37 \\
\hline${\mathrm{N}-N H_{4}{ }^{+}}^{-3}$ & {$\left[\mathrm{mg} \cdot \mathrm{dm}^{-3}\right]$} & 66 & 0.41 & 0.06 & 1.55 & 0.29 & 70.82 \\
\hline $\mathrm{N}_{\text {Kieldahl }}$ & {$\left[\mathrm{mg} \cdot \mathrm{dm}^{-3}\right]$} & 73 & 1.93 & 0.67 & 4.80 & 0.72 & 37.56 \\
\hline $\mathrm{NO}_{3}^{-}$ & {$\left[\mathrm{mg} \cdot \mathrm{dm}^{-3}\right]$} & 70 & 9.51 & 2.10 & 32.30 & 5.92 & 62.17 \\
\hline${\mathrm{N}-\mathrm{NO}_{3}-}^{-}$ & {$\left[\mathrm{mg} \cdot \mathrm{dm}^{-3}\right]$} & 60 & 1.99 & 0.05 & 6.71 & 1.11 & 55.78 \\
\hline $\mathrm{NO}_{2}^{-}$ & {$\left[\mathrm{mg} \cdot \mathrm{dm}^{-3}\right]$} & 73 & 0.12 & 0.01 & 0.42 & 0.08 & 66.69 \\
\hline${\mathrm{N}-N O_{2}-}^{-}$ & {$\left[\mathrm{mg} \cdot \mathrm{dm}^{-3}\right]$} & 60 & 0.04 & 0.00 & 0.13 & 0.03 & 66.09 \\
\hline $\mathrm{N}_{\text {tot }}$ & {$\left[\mathrm{mg} \cdot \mathrm{dm}^{-3}\right]$} & 73 & 3.97 & 0.80 & 10.00 & 1.64 & 41.36 \\
\hline $\mathrm{PO}_{4}{ }^{3-}$ & {$\left[\mathrm{mg} \cdot \mathrm{dm}^{-3}\right]$} & 73 & 0.58 & 0.16 & 3.64 & 0.52 & 88.57 \\
\hline $\mathrm{P}_{\text {tot }}$ & {$\left[\mathrm{mg} \cdot \mathrm{dm}^{-3}\right]$} & 75 & 0.29 & 0.07 & 1.69 & 0.22 & 76.15 \\
\hline Electrical conductivity & {$\left[\mu \mathrm{s} \cdot \mathrm{cm}^{-1}\right]$} & 74 & 392.81 & 206.00 & 479.00 & 40.88 & 10.41 \\
\hline
\end{tabular}


Table 4. Results of the factor analysis (rotation method - normalized varimax, determined loads are $>0.7$ ). Measuring point Gródek

\begin{tabular}{|c|c|c|}
\hline Variables & Factor I & Factor II \\
\hline Precipitation & -0.33 & -0.24 \\
\hline Dissolved oxygen & 0.82 & 0.01 \\
\hline $\mathrm{BOD}_{5}$ & 0.13 & 0.57 \\
\hline $\mathrm{COD}_{\mathrm{Mn}}$ & 0.58 & -0.12 \\
\hline $\mathrm{COD}_{\mathrm{Cr}}$ & 0.59 & 0.00 \\
\hline $\mathrm{NH}_{3}$ & -0.06 & 0.92 \\
\hline $\mathrm{N}-\mathrm{NH}_{4}^{+}$ & -0.06 & 0.92 \\
\hline$N_{\text {Kieldahl }}$ & 0.60 & 0.55 \\
\hline $\mathrm{NO}_{3}^{-}$ & 0.85 & 0.09 \\
\hline $\mathrm{N}-\mathrm{NO}_{3}^{-}$ & 0.85 & 0.09 \\
\hline $\mathrm{NO}_{2}^{-}$ & -0.55 & 0.34 \\
\hline $\mathrm{N}-\mathrm{NO}_{2}^{-}$ & -0.55 & 0.34 \\
\hline$N_{\text {tot }}$ & 0.89 & 0.28 \\
\hline $\mathrm{PO}_{4}^{3-}$ & -0.77 & 0.39 \\
\hline$P_{\text {tot }}$ & -0.71 & 0.49 \\
\hline Electrical conductivity & -0.29 & 0.39 \\
\hline \begin{tabular}{|l|} 
Explanation of chemical \\
composition in the Supraśl river \\
water by factor I and II [\%]
\end{tabular} & 37 & 20 \\
\hline
\end{tabular}

worce, any remarkable sources of $\mathrm{N}_{\text {Kieldahl }}, \mathrm{NO}_{3}^{-}$, $\mathrm{N}-\mathrm{NO}_{3}{ }^{-}$and $\mathrm{N}_{\text {tot }}$ cannot be found, but meadows with post-bog soils and their intense performance methods can be the only reason for the water enrichment in nitrogen compounds due to washout by precipitation water. This fact was also reported by Kiryluk (2003) as well as Skorbiłowicz and
Kiryluk (2005). It should be noted that the point in Nowodworce lies in the protection zone of the surface intake of drinking water for Bialystok. The other factor indicates the self-cleaning processes, the consequence of which is decreasing $\mathrm{PO}_{4}^{3-}$ combined with the dissolved oxygen supply. Positive, high factorial loads representing forms of $\mathrm{N}-\mathrm{NH}_{4}{ }^{+}$may prove the presence of unknown source of these compounds above that site. Perhaps wastes of grazing farm animals are the main cause of the ammonia penetration into the Supraśl river water.

The last measuring point Dzikie is situated directly after the Biała river estuary to the Supraśl river. Therefore, there was a significant dispersion of results related to the water tests in the case of: $\mathrm{NH}_{3}, \mathrm{~N}_{-} \mathrm{NH}_{4}^{+}, \mathrm{NO}_{2}^{-}, \mathrm{N}_{-} \mathrm{NO}_{2}^{-}$and $\mathrm{PO}_{4}{ }^{3-}$ (Table 7). Diversity and variability of the chemical composition of water may result from the enrichment of the Biała river water due to the infrastructure of Białystok it flows through. The first and second factor in factor analysis (Table 8) confirm the processes of enrichment in these components. The processes of nitrogen leaching from the post-bog soils present in that region of the Supraśl river catchment can occur at this point.

\section{CONCLUSIONS}

1. The study and test results allowed for identification of the self-cleaning, nitrification, de-nitrification, and enrichment processes affecting the

Table 5. Mean concentration of components in the Supraśl river water at the measuring point Nowodworce

\begin{tabular}{|c|c|c|c|c|c|c|c|}
\hline Parameter & Unit & $\begin{array}{l}\text { Number of } \\
\text { samples }\end{array}$ & $\begin{array}{c}\text { Arithmetic } \\
\text { mean }\end{array}$ & Minimum & Maximum & $\begin{array}{l}\text { Standard } \\
\text { deviation }\end{array}$ & $\begin{array}{c}\text { Variability } \\
\text { coefficient [\%] }\end{array}$ \\
\hline Precipitation & {$[\mathrm{mm}]$} & 84 & 54.62 & 0.08 & 225.20 & 35.13 & 64.31 \\
\hline Dissolved oxygen & {$\left[\mathrm{mgO}_{2} \cdot \mathrm{dm}^{-3}\right]$} & 117 & 9.77 & 3.30 & 16.30 & 2.28 & 23.35 \\
\hline $\mathrm{BOD}_{5}$ & {$\left[\mathrm{mgO}_{2} \cdot \mathrm{dm}^{-3}\right]$} & 117 & 2.04 & 0.70 & 5.80 & 0.89 & 43.63 \\
\hline $\mathrm{COD}_{\mathrm{Mn}}$ & {$\left[\mathrm{mgO}_{2} \cdot \mathrm{dm}^{-3}\right]$} & 57 & 12.63 & 5.30 & 23.30 & 4.49 & 35.56 \\
\hline $\mathrm{COD}_{\mathrm{Cr}}$ & {$\left[\mathrm{mgO}_{2} \cdot \mathrm{dm}^{-3}\right]$} & 99 & 39.39 & 0.00 & 93.00 & 21.14 & 53.67 \\
\hline $\mathrm{NH}_{3}$ & {$\left[\mathrm{mg} \cdot \mathrm{dm}^{-3}\right]$} & 89 & 0.17 & 0.05 & 0.50 & 0.09 & 50.31 \\
\hline $\mathrm{N}^{-\mathrm{NH}_{4}}{ }^{+}$ & {$\left[\mathrm{mg} \cdot \mathrm{dm}^{-3}\right]$} & 59 & 0.14 & 0.04 & 0.39 & 0.08 & 53.05 \\
\hline $\mathrm{N}_{\text {Kieldahl }}$ & {$\left[\mathrm{mg} \cdot \mathrm{dm}^{-3}\right]$} & 101 & 0.90 & 0.33 & 1.70 & 0.29 & 32.13 \\
\hline $\mathrm{NO}_{3}^{-}$ & {$\left[\mathrm{mg} \cdot \mathrm{dm}^{-3}\right]$} & 100 & 4.91 & 0.50 & 19.50 & 3.18 & 64.90 \\
\hline $\mathrm{N}-\mathrm{NO}_{3}^{-}$ & {$\left[\mathrm{mg} \cdot \mathrm{dm}^{-3}\right]$} & 84 & 1.08 & 0.00 & 4.41 & 0.69 & 63.94 \\
\hline $\mathrm{NO}_{2}^{-}$ & {$\left[\mathrm{mg} \cdot \mathrm{dm}^{-3}\right]$} & 86 & 0.70 & 0.01 & 9.70 & 1.87 & 267.03 \\
\hline $\mathrm{N}-\mathrm{NO}_{2}^{-}$ & {$\left[\mathrm{mg} \cdot \mathrm{dm}^{-3}\right]$} & 62 & 0.01 & 0.00 & 0.02 & 0.01 & 46.55 \\
\hline$N_{\text {tot }}$ & {$\left[\mathrm{mg} \cdot \mathrm{dm}^{-3}\right]$} & 80 & 1.96 & 0.00 & 6.00 & 1.06 & 54.06 \\
\hline $\mathrm{PO}_{4}^{3-}$ & {$\left[\mathrm{mg} \cdot \mathrm{dm}^{-3}\right]$} & 102 & 0.22 & 0.10 & 0.56 & 0.09 & 38.93 \\
\hline$P_{\text {tot }}$ & {$\left[\mathrm{mg} \cdot \mathrm{dm}^{-3}\right]$} & 87 & 0.15 & 0.04 & 0.33 & 0.05 & 35.53 \\
\hline Electrical conductivity & {$\left[\mu \mathrm{S} \cdot \mathrm{cm}^{-1}\right]$} & 117 & 383.56 & 249.00 & 447.00 & 27.13 & 7.07 \\
\hline
\end{tabular}


Table 6. Results of the factor analysis (rotation method - normalized varimax, determined loads are $>0.7$ ). Measuring point Nowodworce

\begin{tabular}{|l|c|c|}
\hline \multicolumn{1}{|c|}{ Variables } & Factor I & Factor II \\
\hline Precipitation & -0.21 & -0.55 \\
\hline Dissolved oxygen & 0.33 & $\mathbf{0 . 7 8}$ \\
\hline $\mathrm{BOD}_{5}$ & 0.44 & 0.64 \\
\hline $\mathrm{COD}_{\mathrm{Mn}}$ & $\mathbf{0 . 8 1}$ & -0.21 \\
\hline $\mathrm{COD}_{\mathrm{Cr}}$ & $\mathbf{0 . 7 0}$ & -0.13 \\
\hline $\mathrm{NH}_{3}$ & -0.05 & $\mathbf{0 . 8 4}$ \\
\hline${\mathrm{N}-\mathrm{NH}_{4}{ }^{+}}$ & -0.05 & 0.84 \\
\hline $\mathrm{N}_{\text {Kieldahl }}$ & $\mathbf{0 . 8 1}$ & 0.31 \\
\hline $\mathrm{NO}_{3}^{-}$ & $\mathbf{0 . 8 4}$ & 0.40 \\
\hline${\mathrm{N}-\mathrm{NO}_{3}{ }^{-}}^{-}$ & $\mathbf{0 . 8 4}$ & 0.40 \\
\hline $\mathrm{NO}_{2}^{-}$ & 0.62 & 0.25 \\
\hline${\mathrm{N}-\mathrm{NO}_{2}{ }^{-}}^{-}$ & 0.63 & 0.24 \\
\hline $\mathrm{N}_{\text {tot }}$ & $\mathbf{0 . 8 8}$ & 0.39 \\
\hline $\mathrm{PO}_{4}{ }^{-}$ & 0.24 & -0.72 \\
\hline $\mathrm{P}_{\text {tot }}$ & 0.19 & -0.07 \\
\hline Electrical conductivity & -0.80 & 0.16 \\
\hline $\begin{array}{l}\text { Explanation of chemical } \\
\text { composition in the Supraśl river } \\
\text { water by factor I and II [\%] }\end{array}$ & 42 & 20 \\
\hline
\end{tabular}

Table 8. Results of the factor analysis (rotation method - normalized varimax, determined loads are $>0.7$ ). Measuring point Dzikie

\begin{tabular}{|l|c|c|}
\hline \multicolumn{1}{|c|}{ Variables } & Factor I & Factor II \\
\hline Precipitation & -0.44 & 0.16 \\
\hline Dissolved oxygen & 0.46 & -0.60 \\
\hline $\mathrm{BOD}_{5}$ & 0.67 & 0.32 \\
\hline $\mathrm{COD}_{\mathrm{Mn}}$ & 0.25 & 0.09 \\
\hline $\mathrm{COD}_{\mathrm{Cr}}$ & 0.05 & 0.43 \\
\hline $\mathrm{NH}_{3}$ & $\mathbf{0 . 7 5}$ & 0.48 \\
\hline${\mathrm{N}-\mathrm{NH}_{4}{ }^{+}}^{\mathrm{N}_{\text {Kieldahl }}}$ & $\mathbf{0 . 7 3}$ & 0.49 \\
\hline $\mathrm{NO}_{3}^{-}$ & $\mathbf{0 . 7 3}$ & 0.26 \\
\hline $\mathrm{N}-\mathrm{NO}_{3}^{-}$ & $\mathbf{0 . 8 8}$ & -0.20 \\
\hline $\mathrm{NO}_{2}^{-}$ & $\mathbf{0 . 8 9}$ & -0.20 \\
\hline $\mathrm{N}-\mathrm{NO}_{2}^{-}$ & 0.01 & $\mathbf{0 . 7 2}$ \\
\hline $\mathrm{N}_{\text {tot }}^{-}$ & 0.01 & $\mathbf{0 . 7 2}$ \\
\hline $\mathrm{PO}_{4}{ }^{-}$ & $\mathbf{0 . 9 4}$ & 0.00 \\
\hline $\mathrm{P}_{\text {tot }}$ & -0.08 & 0.59 \\
\hline Electrical conductivity & 0.35 & 0.65 \\
\hline $\begin{array}{l}\text { Explanation of chemical } \\
\text { composition in the Supraśl river } \\
\text { water by factor I and II [\%] }\end{array}$ & 0.32 & 0.51 \\
\hline
\end{tabular}

Table 7. Mean concentration of components in the Supraśl river water at the measuring point Dzikie

\begin{tabular}{|c|c|c|c|c|c|c|c|}
\hline Parameter & Unit & $\begin{array}{c}\text { Number of } \\
\text { samples }\end{array}$ & Arithmetic mean & Minimum & Maximum & $\begin{array}{l}\text { Standard } \\
\text { deviation }\end{array}$ & $\begin{array}{c}\text { Variability } \\
\text { coefficient [\%] }\end{array}$ \\
\hline Precipitation & {$[\mathrm{mm}]$} & 94 & 55.44 & 0.08 & 225.20 & 35.00 & 63.13 \\
\hline Dissolved oxygen & {$\left[\mathrm{mgO}_{2} \cdot \mathrm{dm}^{-3}\right]$} & 96 & 9.92 & 5.30 & 17.60 & 2.11 & 21.23 \\
\hline $\mathrm{BOD}_{5}$ & {$\left[\mathrm{mgO}_{2} \cdot \mathrm{dm}^{-3}\right]$} & 96 & 2.70 & 0.60 & 10.00 & 1.37 & 50.80 \\
\hline $\mathrm{COD}_{\mathrm{Mn}}$ & {$\left[\mathrm{mgO}_{2} \cdot \mathrm{dm}^{-3}\right]$} & 95 & 12.45 & 6.60 & 24.80 & 3.78 & 30.32 \\
\hline $\mathrm{COD}_{\mathrm{Cr}}$ & {$\left[\mathrm{mgO}_{2} \cdot \mathrm{dm}^{-3}\right]$} & 84 & 44.93 & 4.53 & 96.30 & 21.90 & 48.75 \\
\hline $\mathrm{NH}_{3}$ & {$\left[\mathrm{mg} \cdot \mathrm{dm}^{-3}\right]$} & 84 & 0.26 & 0.05 & 1.70 & 0.26 & 102.26 \\
\hline $\mathrm{N}-\mathrm{NH}_{4}^{+}$ & {$\left[\mathrm{mg} \cdot \mathrm{dm}^{-3}\right]$} & 96 & 0.18 & 0.04 & 1.32 & 0.20 & 108.55 \\
\hline$N_{\text {Kieldahl }}$ & {$\left[\mathrm{mg} \cdot \mathrm{dm}^{-3}\right]$} & 96 & 1.24 & 0.44 & 3.30 & 0.45 & 35.79 \\
\hline $\mathrm{NO}_{3}^{-}$ & {$\left[\mathrm{mg} \cdot \mathrm{dm}^{-3}\right]$} & 84 & 8.21 & 2.10 & 22.10 & 2.84 & 34.63 \\
\hline $\mathrm{N}-\mathrm{NO}_{3}^{-}$ & {$\left[\mathrm{mg} \cdot \mathrm{dm}^{-3}\right]$} & 96 & 1.88 & 0.48 & 5.20 & 0.78 & 41.32 \\
\hline $\mathrm{NO}_{2}^{-}$ & {$\left[\mathrm{mg} \cdot \mathrm{dm}^{-3}\right]$} & 96 & 0.13 & 0.03 & 0.93 & 0.13 & 98.66 \\
\hline $\mathrm{N}-\mathrm{NO}_{2}^{-}$ & {$\left[\mathrm{mg} \cdot \mathrm{dm}^{-3}\right]$} & 95 & 0.04 & 0.01 & 0.28 & 0.04 & 98.66 \\
\hline $\mathrm{N}_{\text {tot }}$ & {$\left[\mathrm{mg} \cdot \mathrm{dm}^{-3}\right]$} & 96 & 3.18 & 1.70 & 8.60 & 1.10 & 34.49 \\
\hline $\mathrm{PO}_{4}^{3-}$ & {$\left[\mathrm{mg} \cdot \mathrm{dm}^{-3}\right]$} & 96 & 0.29 & 0.10 & 3.04 & 0.31 & 104.53 \\
\hline$P_{\text {tot }}$ & {$\left[\mathrm{mg} \cdot \mathrm{dm}^{-3}\right]$} & 96 & 0.19 & 0.04 & 1.00 & 0.12 & 62.55 \\
\hline Electrical conductivity & {$\left[\mu \mathrm{S} \cdot \mathrm{cm}^{-1}\right]$} & 96 & 479.72 & 315.00 & 986.00 & 85.88 & 17.90 \\
\hline
\end{tabular}

variability of chemical composition in the Supraśl river water.

2. At the measuring points Gródek and Michałowo, sources of $\mathrm{BOD}_{5}, \mathrm{NH}_{3}, \mathrm{~N}-\mathrm{NH}_{4}^{+}, \mathrm{PO}_{4}^{3-}, \mathrm{P}_{\text {tot }}$ were identified. It was the effect of the discharge of insufficiently purified wastewater from municipal sewage treatment plants.
3. The analyses allowed to find the processes of nitrogen leaching from bog-hydrogenic soils into the Supraśl river water at some points.

4. Results of the factor analysis revealed the prevalence of the enrichment over internal conversion processes in the aquatic environment of the Supraśl river. 


\section{REFERENCES}

1. Banaszuk H., Wysocka A. 1996. Wpływ gospodarczej działalności człowieka na procesy geochemiczne w przekształconej dolinie Narwi na obszarze Narwiańskiego Parku Narodowego, Inżynieria środowiska, zesz. nauk. Politechniki Białostockiej 9, Białystok, 143-151.

2. Banaszuk P. 2007. Wodna migracja zanieczyszczeń obszarowych do wód powierzchniowych w zlewni górnej Narwi. Rozpr. Nauk. nr 144. Białystok. Wydaw. Polit. Biał. ss. 182.

3. Banaszuk P.. 2004. Identyfikacja procesów kształtujących skład chemiczny małego cieku w krajobrazie rolniczym na podstawie analizy czynnikowej, Woda-Środowisko-Obszary Wiejskie. 4, 1 (10), Instytut Melioracji i Użytków Zielonych w Falentach, 103-116.

4. Górniak A (red.). 2006. Ekosystem zbiornika Siemianówka w latach 1990-2004 i jego rekultywacja. Zakład Hydrobiologii, Uniwersytet w Białymstoku, ss. 236.

5. Grabowska M., Górniak A., Jekatierynczuk-Rudczyk E., Zieliński P. 2003. The influence of hydrology and water quality on phytoplankton community composition and biomass in a humoeutrofic reservoir, Siemianowka Reservoir (Poland). Ecohydrology and Hydrobiology 3(2), 185-196.

6. Jekaterynczuk-Rudczyk E., Zieliński P., Górniak
A. 2006. Stopień degradacji rzeki wiejskiej w bezpośrednim sąsiedztwie Białegostoku. Woda Środ. Obsz. Wiej. t. 6, z. 2 (18),143-153.

7. Kiryluk A. 2003. Wpływ sposobu użytkowania torfowiska niskiego na zawartość biogenów i innych składników w wodach gruntowych i w wodach $\mathrm{z}$ rowów melioracyjnych na obiekcie Supraśl Dolna. Acta Agrophysica, 87, 1(2), 245-253.

8. Mioduszewski W. 1997. Podstawowe problemy gospodarki wodnej w zlewni górnej Narwi, Stowarzyszenie Inżynierów i Techników Wodnych i Melioracyjnych, Informacje Naukowe i Techniczne, nr. 2, Warszawa.

9. Skorbiłowicz M. 2010. Czynniki i procesy kształtujące obieg składników mineralnych w wodach rzecznych zlewni górnej Narwi, Oficyna Wydawnicza Politechniki Białostockiej, Białystok.

10. Skorbiłowicz M., 2006, Ocena wpływu rodzaju oraz intensywności źródeł zanieczyszczeń wód rzeki Supraśl, Rocz. Glebozn. 57(3/4), 127-134.

11. Skorbiłowicz M., Kiryluk A. 2005. Gleby pobagienne $\mathrm{i}$ ich wpływ na sezonowe zmiany jakości wód rzeki Supraśl. Cz. II. Journal of Elementology, 10(3), 811-819.

12. Skorbiłowicz M., Ofman P., 2015. Changes in specific loads of mineral components outflowing from catchment area of River Supraśl in 2001-2009. J. Ecol. Eng. 16(1), 135-140.

13. http://monitor.pogodynka.pl/\#map/19.533,52.1384 , 7, false,true, 0 